\title{
Clinical response to therapy with thymopoietin pentapeptide (TP-5) in rheumatoid arthritis
}

\author{
E. M. VEYS,$^{1}$ E. C. HUSKISSON ${ }^{2} M$. ROSENTHAL ${ }^{3}{ }^{2}$ T. L. VISCHER,${ }^{4}$ \\ H. MIELANTS,${ }^{5}$ P. A. THROWER, ${ }^{2}$ J. SCOTT,${ }^{2} \mathrm{H}$. OTT,${ }^{6}$ \\ H. SCHEIJGROND, ${ }^{7}$ AND J. SYMOENS ${ }^{7}$
}

From the ${ }^{1}$ Department of Rheumatology, University of Ghent, Belgium; ${ }^{2}$ Department of Rheumatology, St Bartholomew's Hospital, London; ${ }^{3}$ Department of Rheumatology, Merian-Iselin-Spital, Basel, Switzerland; ${ }^{4}$ Division of Rheumatology, University Department of Medicine, Hopital Cantonal, Geneva, Switzerland; ${ }^{5}$ Department of Rheumatology, University of Ghent, Belgium; ${ }^{6}$ Department of Rheumatology, Hopital La Chaux-de-Fonds, La Chaux-de-Fonds, Switzerland; ${ }^{7}$ Department of Clinical Pharmacology, Janssen Pharmaceutica, Beerse, Belgium (co-ordination).

SUMMARY The effect of thymopoietin pentapeptide (TP-5) was evaluated in patients with rheumatoid arthritis (RA). Ninety-two patients were divided into 3 groups, namely, placebo, TP-5 intramuscularly (IM) $1 \mathrm{mg}$, TP-5 intravenously (IV) $50 \mathrm{mg}$, and were evaluated for 6 measures of disease activity at the beginning of the study and at 3 and 6 months. No difference was observed between the placebo group and the group treated with TP-5 IM $1 \mathrm{mg}$. However, in the group treated with TP-5 IV $50 \mathrm{mg}$ a statistically significant improvement of all parameters except the ESR was observed.

Thymopoietin, a polypeptide hormone isolated from thymic extracts, has been shown to affect immunoregulation by a number of mechanisms: induction of early $\mathrm{T}$ cell differentiation, inhibition of $B$ cell differentiation, and modulation of mature lymphocytes. ${ }^{1-3}$ The pentapeptide TP-5, corresponding to residues 32-36 of thymopoietin, has been shown to retain the biological activity of thymopoietin and thus probably corresponds to the active site of the parent molecule. ${ }^{4}$ Preclinical animal studies with TP-5 have demonstrated a lack of toxicity at dosage levels up to 500 times that which is administered to humans. It is noteworthy that TP-5 is rapidly degraded to its component amino acids in human plasma ( $\left(\frac{1}{2} \sim 30 \mathrm{~s}\right)$ and that this may account for the lack of toxicity. ${ }^{5}$

One current hypothesis on the pathogenesis of rheumatoid arthritis (RA) has suggested a defect of immune regulation. ${ }^{6}$ Failure of cell-mediated immunity to eliminate pathogen and failure of suppressor $\mathrm{T}$ cells to regulate the immune response could explain B cell hyperactivity and chronic inflammation in patients with RA. ${ }^{7}$ The clinical application of an immunoregulator, such as TP-5, may provide a new approach to the treatment of RA. In this study, 4

Accepted for publication 18 August 1981

Correspondence to Dr J. Symoens, Department of Clinical Research, Janssen Pharmaceutica, B-2340 Beerse, Belgium. centres collaborated to evaluate the effectiveness of $\mathrm{TP}-5$ and to compare the efficacy of 2 dosage regimens.

\section{Patients and methods}

INVESTIGATION PLAN

This paper describes the results of 2 studies. In the first study, which was double-blind and ran from September 1978 to December 1979, TP-5 was administered at a dosage of $1 \mathrm{mg}$ intramuscularly (IM) once weekly and was compared with a control group receiving intramuscular injections of $1 \mathrm{ml}$ physiological saline at the same frequency. TP-5 was dissolved in physiological saline at $1 \mathrm{mg} / \mathrm{ml}$. The study medications were specially packaged to ensure that the study was double-blind.

In the second study, which was open and ran from December 1978 to May $1980,50 \mathrm{mg}$ of TP-5 was administered intravenously (IV) once weekly. The controls of the first study were used for comparison.

\section{PATIENTS}

The study patients were outpatients with definite or classic rheumatoid arthritis of at least 6 months' duration, as defined by the American Rheumatism Association criteria, ${ }^{8}$ and with active disease defined by the presence of 3 out of the 4 following criteria: 
number of joints painful or tender on motion $(>6)$, number of joints swollen $(>3)$, duration of morning stiffness ( $>$ three-quarters of an hour), and Westergren erythrocyte sedimentation rate $(>28 \mathrm{~mm} / \mathrm{h})$. Another criterion was that the disease was not controlled by, or that it progressed despite, the optimal use of anti-inflammatory drugs. Patients were excluded who were unreliable, under 16 years of age, pregnant, or had been treated with basic antirheumatics (such as gold, levamisole, D-penicillamine, antimalarials, or immunosuppressives) during the 3 months preceding the start of the trial.

\section{CONCOMITANT THERAPY}

Patients continued to take the analgesic or antiinflammatory drugs they were taking on admission. Doses of concomitant drugs could be increased or decreased during the trial, but not during the last month before admission to the study. Doses of corticosteroids were limited to the equivalent of $10 \mathrm{mg}$ of prednisolone daily. No new anti-inflammatory, analgesic, or antirheumatic therapy was started from one month before the start of the trial until its end.

\section{CLINICAL AND BIOLOGICAL ASSESSMENTS}

The clinical status of the patients was evaluated by the same investigator at the start, at the end of 3 months of treatment, and at the end of 6 months of treatment. The clinical parameters assessed were the Ritchie index, ${ }^{9}$ the number of tender and of swollen joints, pain measured by Huskisson's visual analogue method, ${ }^{10}$ the duration of morning stiffness, and the erythrocyte sedimentation rate (ESR) by the Westergren method. At each visit the patient was asked about adverse experiences without the investigator suggesting that these could be expected.

\section{DATA ANALYSIS}

All data were recorded on standard record forms and sent to the co-ordination centre for analysis. Nonparametric tests were used for statistical analysis. Changes observed in treatment groups between each individual at the start and 3 months and at the start and 6 months (intragroup changes) were evaluated by the Wilcoxon matched-pairs signed-ranks test. ${ }^{11}$ Individual response to treatment was evaluated by means of a mathematical model designed by Lewi and Symoens ${ }^{12}$ which expresses by one score the degree of change in 6 measures of disease activity: Ritchie index, number of tender and of swollen joints, pain, morning stiffness, and ESR. A global score of zero indicates no change, negative scores indicate deterioration, and positive ones improvement. Statistical analysis of the global response to treatment was done by means of chi-square analysis.

\section{Results}

\section{PATIENTS}

Ninety-two patients entered the 2 studies; 20 were in the control group, 21 in the group receiving $1 \mathrm{mg}$ of TP- 5 by IM injection once weekly, and 51 in the group receiving $50 \mathrm{mg}$ of TP-5 by IV injection once weekly. Sixteen of the 20 patients in the control group, 15 of the 21 patients in the TP-5 $1 \mathrm{mg}$ group, and 44 of 51 patients in the TP-5 $50 \mathrm{mg}$ group completed the 6-month trial (Table 1 ). No withdrawals for adverse reactions were observed.

\section{EFFICACY}

Table 2 shows the median values in the various measures of disease activity and the statistical significance in the changes of the median values at 3 and 6 months for placebo and both treatment groups when compared with initial values. Since the final parameters were missing for patients who dropped out of the study because of inefficacy, a no-change value was given for each parameter in such patients. This prevented overstatement of efficacy.

After 3 months of treatment neither the placebo group nor the TP-5 $1 \mathrm{mg}$ group showed statistically significant $(p<0.05)$ improvement for any individual measurement. After 6 months of treatment the TP-5 $1 \mathrm{mg}$ group showed a statistically significant decrease in the number of swollen joints $(p<0.007)$, morning stiffness $(p<0 \cdot 0005)$, and pain $(p<0 \cdot 04)$. However, in the placebo group, a statistically significant decrease was also observed in the number of swollen joints $(p<0.04)$, morning stiffness $(p<0.03)$, and pain $(p<0.006)$. No changes were observed in the ESR in either group, and the global scores reflected the overall lack of improvement seen in both groups.

After 3 months of treatment in the TP-5 $50 \mathrm{mg}$ group a statistically significant improvement was observed in all parameters $(p<0 \cdot 01)$ except the ESR. After 6 months of treatment, this group showed a statistically significant improvement in all parameters $(p<0.005)$ except for the ESR.

Table 3 shows the global response to treatment, as indicated by global scores and withdrawal for inefficacy. The overall results of treatment with $50 \mathrm{mg}$ TP-5 intravenously were significantly better than with placebo $(p=0.005)$ and with $1 \mathrm{mg}$ TP-5

Table 1 Number of patients studied

\begin{tabular}{lcll}
\hline & Control & \multicolumn{2}{l}{$T P-5$} \\
\cline { 3 - 4 } & & I mg IM & 50 mg IV \\
\hline Start & 20 & 21 & 51 \\
Evaluable at 3 months & 20 & 21 & 51 \\
Evaluable at 6 months & 16 & 15 & 44 \\
Withdrawn, inefficacy & 4 & 3 & 0 \\
Withdrawn, other reason & 0 & 2 & 0 \\
Lost to follow-up & 0 & 1 & 7 \\
\hline
\end{tabular}


Table 2 Changes of measures during treatment (median values)

\begin{tabular}{|c|c|c|c|c|c|c|c|c|c|}
\hline & \multicolumn{3}{|c|}{ Placebo IM } & \multicolumn{3}{|c|}{$1 \mathrm{mg}$ of $T P-5 I M$} & \multicolumn{3}{|c|}{$50 \mathrm{mg}$ of $T P-5 \mathrm{IV}$} \\
\hline & $\begin{array}{l}\text { Start } \\
(n=20)\end{array}$ & $\begin{array}{l}3 \text { Mos. } \\
(n=20)\end{array}$ & $\begin{array}{l}6 \text { Mos. } \\
(n=16)\end{array}$ & $\begin{array}{l}\text { Start } \\
(n=21)\end{array}$ & $\begin{array}{l}3 M o s \\
(n=21)\end{array}$ & $\begin{array}{l}\text { 6Mos. } \\
(n=15)\end{array}$ & $\begin{array}{l}\text { Start } \\
(n=51)\end{array}$ & $\begin{array}{l}3 \text { Mos. } \\
(n=51)\end{array}$ & $\begin{array}{l}6 \text { Mos. } \\
(n=44)\end{array}$ \\
\hline Ritchie index & $24 \cdot 5$ & $\begin{array}{l}21 \\
\text { NS }\end{array}$ & $\begin{array}{c}22.5 \\
0.04\end{array}$ & 26 & $\begin{array}{l}23 \\
\text { NS }\end{array}$ & $\begin{array}{l}21 \\
\text { NS }\end{array}$ & 21 & $\begin{array}{l}13 \\
<0.0001\end{array}$ & $\begin{array}{l}11 \\
<0.0001\end{array}$ \\
\hline Number of tender joints & 14 & $\begin{array}{l}12 \cdot 5 \\
\text { NS }\end{array}$ & $\begin{array}{l}12 \cdot 5 \\
\text { NS }\end{array}$ & 14 & $\begin{array}{l}14 \\
\text { NS }\end{array}$ & $\begin{array}{l}14 \\
\text { NS }\end{array}$ & 13 & $\begin{array}{l}10 \\
<0.0001\end{array}$ & $\begin{array}{l}.8 \\
<0.0001\end{array}$ \\
\hline Number of swollen joints & $8 \cdot 5$ & $\begin{array}{l}7 \cdot 5 \\
\text { NS }\end{array}$ & $\begin{array}{l}8 \\
0.04\end{array}$ & 7 & $\begin{array}{c}6 \\
\text { NS }\end{array}$ & $\begin{array}{c}6 \\
0.007\end{array}$ & 8 & $\begin{array}{c}6 \\
0.004\end{array}$ & $\begin{array}{c}6 \\
0.0005\end{array}$ \\
\hline Pain (mm) & $60 \cdot 5$ & $\begin{array}{l}55 \cdot 5 \\
\text { NS }\end{array}$ & $\begin{array}{l}45 \\
0.006\end{array}$ & 65 & $\begin{array}{l}58 \\
\text { NS }\end{array}$ & $\begin{array}{l}60 \\
0.04\end{array}$ & 56 & $\begin{array}{l}42 \\
0 \cdot 002\end{array}$ & $\begin{array}{l}33 \\
<0.0001\end{array}$ \\
\hline $\begin{array}{l}\text { Morning stiffness } \\
\text { (min.) }\end{array}$ & 60 & $\begin{array}{l}45 \\
\text { NS }\end{array}$ & $\begin{array}{l}30 \\
0.03\end{array}$ & 60 & $\begin{array}{l}60 \\
\text { NS }\end{array}$ & $\begin{array}{l}30 \\
0 \cdot 0005\end{array}$ & 60 & $\begin{array}{l}30 \\
0 \cdot 006\end{array}$ & $\begin{array}{l}30 \\
0.0003\end{array}$ \\
\hline $\begin{array}{l}\text { Sedimentation rate } \\
(\mathrm{mm} / \mathrm{h})\end{array}$ & $44 \cdot 5$ & $\begin{array}{l}54 \\
\text { NS }\end{array}$ & $\begin{array}{l}45 \\
\text { NS }\end{array}$ & 35 & $\begin{array}{l}31 \cdot 5 \\
\text { NS }\end{array}$ & $\begin{array}{l}37 \\
\text { NS }\end{array}$ & 48 & $\begin{array}{l}46 \\
\text { NS }\end{array}$ & $\begin{array}{l}44 \\
\text { NS }\end{array}$ \\
\hline
\end{tabular}

Statistical changes were evaluated by Wilcoxon matched-pairs signed-ranks test, 2-tailed. NS=not significant.

Table 3 Global responses at 6 months (\% of patients)

\begin{tabular}{lcll}
\hline Global response & $\begin{array}{l}\text { Control } \\
(n=20)\end{array}$ & $\begin{array}{l}T P-5 \\
(1 \text { mg IM }) \\
(n=18)\end{array}$ & $\begin{array}{l}\text { TP-5 } \\
(50 \text { mg IV }) \\
(n=44)\end{array}$ \\
\hline Marked improvement $\left(>130^{*}\right)$ & 0 & 6 & 18 \\
Moderate improvement $\left(0-130^{*}\right)$ & 55 & 55 & 64 \\
Deterioration $\left(<0^{*}\right)$ & 25 & 22 & 18 \\
Withdrawn inefficacy & 20 & 17 & 0 \\
\hline
\end{tabular}

*Global score.

intramuscularly $(p=0.030)$. The results are not significantly different between $1 \mathrm{mg}$ TP-5 intramuscularly and placebo.

\section{ADVERSE REACTIONS}

One patient in the $1 \mathrm{mg}$ TP-5 group experienced fever; in the $50 \mathrm{mg} \mathrm{TP}-5$ group 2 patients reported a skin rash, one reported herpes zoster, and one reported diarrhoea. It is not clear whether. these adverse reactions were related to TP-5 treatment.

\section{Discussion}

The results showed that there was no statistical difference between the placebo group and the group treated with $1 \mathrm{mg}$ TP-5 by intramuscular injection once per week. In the group treated with $50 \mathrm{mg}$ of TP- 5 by intravenous injection once per week a suppression of the clinical manifestation of the disease was observed. This improvement was similar in time course to that obtained with slow-acting antirheumatic drugs, gold, D-penicillamine, and levamisole. ${ }^{13} 14$ The one index that did not follow this improvement was the ESR. It should be noted that suboptimal regimens of levamisole present a similar picture of clinical improvement without improvement in ESR, whereas optimal levamisole regimens result in both clinical improvement and a lowering of ESR. ${ }^{14}$ This suggests that the once-weekly treatment schedule used in this investigation may not have been optimal. These data, evaluated in an open study, need to be repeated and confirmed in double-blind controlled investigations before we can be confident that TP-5 is therapeutically effective in rheumatoid arthritis.

We thank Drs Gideon Goldstein and Paul Janssen for advice and help when preparing this trial.

\section{References}

${ }^{1}$ Goldstein G. Isolation of bovine thymin: a polypeptide hormone of the thymus. Nature $1974 ; 247: 11-4$.

${ }^{2}$ Basch R S, Goldstein G. Induction of T-cell differentiation in vitro by thymin, a purified polypeptide hormone of the thymus. Proc Natl Acad Sci USA 1974; 71: 1474-8.

${ }^{3}$ Scheid M P, Goldstein G, Boyse E A. The generation and regulation of lymphocyte populations. J Exp Med 1978; 147: 1727-43.

4 Goldstein G, Scheid M P, Boyse E A, Schlesinger D H, Van Wauwe J. A synthetic pentapeptide with biological activity. Characteristic of the thymic hormone thymopoietin. Science 1979; 204: 1309-10.

5 Tischio J P, Patrick J E, Weintraub H S, Chasin M, Goldstein G. Short in vitro half-life of thymopoietin 32-36 pentapeptide in human plasma. Int J Peptide Protein Res 1979; 14: 479-84.

- Paget S A, Gibofsky A. Immunopathogenesis of rheumatoid arthritis. Aim J Med 1979; 67: 961-70.

7 Symoens $J$. The rationale of using levamisole in the treatment of rheumatoid arthritis. In: Willoughby D A, Giroud J P, Velo G P, eds. Perspectives in Inflammation. Lancaster: MTP Press, 1977: 11-20.

${ }^{8}$ Cooperating Clinics Committee of American Rheumatism Association. Arthritis Rheum 1965; 8: 302-34.

- Ritchie D M, Boyle J A, McInnes J M, et al. Clinical studies with an articular index for the assessment of joint tenderness in patients with rheumatoid arthritis. $Q J$ Med 1968; 37: 393-406.

${ }^{10}$ Huskisson E C. Measurement of pain. Lancet 1974; iz: 1127-31.

${ }^{11}$ Siegel P J. Nonparametric Statistics. New York: McGraw-Hill, 1956.

12 Lewi P J, Symoens J. Levamisole in rheumatoid arthritis: a multivariate analysis of a multicentric study. $J$ Rheumatol 1978; 5 (suppl 4): 17-26.

${ }^{13}$ Currey H L F, Harris J, Mason R M, et al. Comparison of azathioprine, cyclophosphamide, and gold in treatment of rheumatoid arthritis. Br Med J 1974; iii: 763-6.

14 Multicenter Study Group. A multicentre randomized doubleblind study comparing two dosages of levamisole in rheumatoid arthritis. J Rheumatol 1978; 5 (suppl 4): 5-10. 